\title{
FEM simulation of water lost through damaged household water connection
}

\author{
Matgorzata Iwanek $^{1, *}$, Pawet Suchorab ${ }^{1}$, and Zbigniew Suchorab ${ }^{1}$ \\ ${ }^{1}$ Lublin University of Technology, Faculty of Environmental Engineering, Nadbystrzycka 40 B, 20-618 Lublin, Poland
}

\begin{abstract}
The problem of water supply pipe's failures is one of the most onerous for water distribution network's (WDN) operators. Multiple actions undertaken to detect, minimise and eliminate the phenomenon of water losses are mainly focused on financial aspect of lost water. However, at some point, the further minimisation of water losses is unprofitable due to reaching the economic level of water leakages. In WDNs failures analysis the biggest emphasis is put on damages of main pipes and distribution pipes, while failures of household water connections are often neglected. That is because the most typical water losses in household connections are hard-to-detect background leakages with relatively small water outflow. Still, in a long-time perspective, such leakages can cause significant water losses. The aim of this paper was to evaluate the parameters of water lost through damaged household water connection (volume, velocity, suffosion conditions). The basis for the analysis were laboratory investigations and a numerical simulation of a pipe failure using the FEFLOW v. 5.3 software. The results of the simulation, compared with laboratory tests results, enabled to state that, contrary to the widespread practice, leakages from household connections cannot be ignored.
\end{abstract}

\section{Introduction}

Among all components of water supply networks, water supply household connections are mostly threatened with damages. Intensity of damage to the connections is more than three times higher comparing to the main lines, and almost two times higher comparing to the distribution pipelines [1]. The influence of particular factors on the increase in the damage intensity has been investigated in many researches [2-4]. It has been stated that the major cause of high ratio of damage to the connections is the poor technical status of these elements. That is often caused by the material used for mounting, mostly steel, that is prone to internal and external corrosion which decreases strength of material and increases flow resistance, that may lead to pitting and pinholes formation. Other factors that may lead to water supply connection damages are the following [5]: pipeline diameter decrease at junction, frequent pressure variations, flow intensity that may be highly variable in relatively short intervals and susceptibility to freezing during winter period. Additionally, there also exists an administrative factor that may run to the increase in damage ratio of the water supply household connections. According to Polish organisation Izba Gospodarcza "Wodociągi Polskie", [6] - water supply connection is a part of a conduit placed at the area of water supply customer. This definition does not show who is the administrator of the connection - a water supply enterprise or an owner of an estate.

Water supply systems damages, mainly household connection failures, are still the current problem, analysed in the literature in many aspects - forecasting $[7,8]$, analysis of network condition [9, 10], development of techniques of leakage detection and evaluation of technical status of conduits. Among the consequences of the water supply household connections leakages, two items ought to be mentioned. The first and the most obvious is water loss. In case of the household connections, leakages are mostly very small which hinders their detection. Contrary to big damages of pipelines, small amounts of lost water are not visible and may not be quickly noticed by water meters readouts. This extends time of reaction and may lead to greater water loses than in case of big water supply system malfunctions [11]. The key factor, that significantly influences the amount of water loss, is a time interval between the accident and the repair. The time interval can be divided into several stages:

- notification (the time interval between leakage presence and receiving the notification),

- detection (the time interval between receiving the notification and starting the repair),

- repair (from beginning to the end).

From the above consideration it can be assumed that total water loss during pipeline damage is proportional to the sum of time intervals of particular stages and the leakage intensity. According to the literature reports [12] many leakages do not influence the connection performance and may not be reported to the system administrator. Additionally, it happens frequently that the first interval is very long, sometimes exceeding 100 days period [13].

* Corresponding author: m.iwanek@ pollub.pl 
The second consequence of the leakage is the phenomenon of suffosion that could be defined as a process of flushing the small particles from the ground and displacing them which results in the presence of hollows or caverns. These may be particularly harmful in the urbanised areas, constituting the threat of construction disasters, dangerous for the people's lives and generating significant costs for the repairs of the streets or pavements [14-16]. Suffosion is possible if two conditions are met: geometrical - connected with soil physical parameters, and kinematic - connected with velocity of water outflowing from a damaged pipe [17]. Suffosion occurring in soil, as a result of a failure of water pipeline is relatively common problem both in Poland and in the world [18]. The aim of this paper was to estimate the parameters of water lost during a household connection failure, in order to specify the importance of detecting and eliminating leakages from household connections.

\section{Materials and methods}

The investigation included:

- laboratory tests,

- numerical simulation with the FEFLOW software,

- calculations of water outflow velocity and verification of the suffosion effect possibility,

- results comparison with the literature data,

- analysis and verification of the obtained results.

Laboratory investigation of a buried household connection pipe failure was conducted on the setup reflecting real conditions scaled 1:10. Dimensions of the setup were established as a result of dimensional analysis. The main part of the laboratory setup (presented in Fig. 1) consisted of an intentionally damaged water pipe, buried in medium sand filling a cuboid box. The pipe was supplied with water from a container located on the assumed height. A pipe DN6 mm (reflecting DN65 mm household connection) leaking through a whole circumference with the internal water pressure head in the pipe equalled $4 \mathrm{~m} \mathrm{H}_{2} \mathrm{O}$ (reflecting $40 \mathrm{~m} \mathrm{H}_{2} \mathrm{O}$ ) was tested. The experiment was repeated 6 times. Details about the laboratory setup construction, the experiment methodology and performance are given in [19].

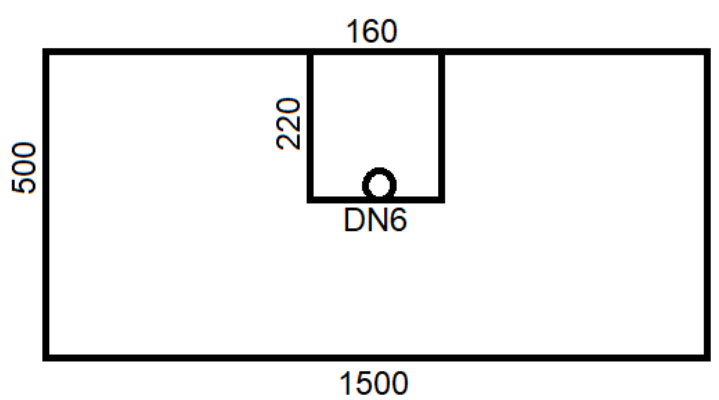

Fig. 1. Cross-section of a laboratory setup main part.

The numerical simulation was conducted in the FEFLOW v. 5.3 software, using the finite element analysis (FEM) to solve the groundwater flow equation of both saturated and unsaturated media. This software is a useful tool for simulation of natural water flow in the porous media, mainly grounds [20, 21]. Additionally, it can be successfully applied to simulations of water flows from the damaged pipeline of the water supply or sewage disposal networks $[22,23]$. Conditions of the simulation were corresponding to the laboratory tests the gap in the leaking pipe was a whole circumference of the pipe. The simulation required creating a 2dimentional soil profile $(1.5 \mathrm{~m} \times 0.5 \mathrm{~m})$, reflecting the cross section of a laboratory setup, including a pipe DN6 $\mathrm{mm}$ in the bottom of an excavation. The 2dimentional soil profile was further meshed with 2447 triangle elements and 1293 nodes. The mesh was generated automatically with user's refinements of elements in the excavation. Two kinds of boundary conditions were implemented into the model: the first type - Neumann boundary condition - to reflect the evaporation and impermeable layer, and the second type - Dirichlet boundary condition - to reflect the leaking part of the household connection. Additionally, three referential points were assigned, in order to observe the saturation level at different places of the excavation. The boundary conditions, part of the finite element mesh and location of reference points are presented in Fig. 2 and Fig. 3. The flow in unsaturated media was calculated in reference to standard Richards equation, with the automatic time step control via aggressive target-based strategies (backward Euler scheme). The initial time step length was equal to 0.00002 day, with final time equal to 0.1 day. Mualem model parameters of soils are given in table 1 .

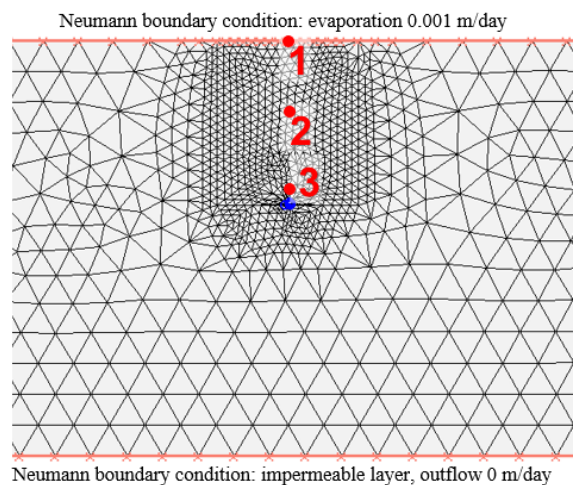

Fig. 3. Boundary conditions and a part of finite element mesh in the soil profile.

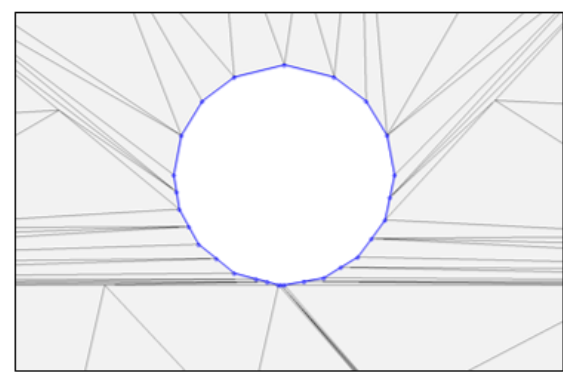

Dirichlet boundary condition: $\mathrm{H}=4 \mathrm{~m} \mathrm{H}_{2} \mathrm{O}$

Fig. 2. Boundary conditions and a part of finite element mesh around the household connection pipe. 
Table 1. Hydraulic parameters of soils used in the simulation in accordance to Mualem model.

\begin{tabular}{|c|c|c|c|c|c|}
\hline \multirow{2}{*}{ soil } & $\theta$ & $K S$ & $P$ & $\alpha$ & $n$ \\
\cline { 2 - 6 } & $\begin{array}{c}\% \\
(\mathrm{vol} .)\end{array}$ & $\begin{array}{c}\cdot 10^{-4} \\
\mathrm{~m} / \mathrm{s}\end{array}$ & $\begin{array}{c}\% \\
(\mathrm{vol} .)\end{array}$ & $1 / \mathrm{m}$ & - \\
\hline $\begin{array}{c}\text { in the } \\
\text { excavation }\end{array}$ & 0.177 & 3.34 & 36.12 & 1.662 & 1.334 \\
\hline $\begin{array}{c}\text { around the } \\
\text { excavation }\end{array}$ & 0.146 & 1.40 & 26.56 & 2.170 & 2.133 \\
\hline
\end{tabular}

$\theta$ - volumetric water content $\left(\mathrm{m}^{3} / \mathrm{m}^{3}\right)$

$K_{S}-$ saturated hydraulic conductivity coefficient $(\mathrm{m} / \mathrm{s})$

$P$ - porosity

$\alpha, n-$ fitting parameters, $(1 / \mathrm{m},-)$

As the final part of the analysis, the hydraulic condition of the possibility of occurrence of suffosion effect was verified. In order to evaluate whether the suffosion effect is possible or not, it was necessary to calculate the water outflow velocity. The water outflow velocity was computed using the continuity equation (1), based on the previous results of the total integral water flux. Next, the obtained result of water flow critical velocity was compared with literature values of critical water velocity, calculated in accordance to Sichardt (2) [24], Abramov (3) [25] and Schmieder (4) [26] formulas. The suffosion effect is possible to occur when the outflow velocity is greater than critical water outflow velocity, which can cause the washing out of solid particles from the soil matrix.

$$
\begin{gathered}
v_{\text {out }}=\frac{Q}{A} \\
v_{c r}=\frac{1}{15} \sqrt{K_{s}} \\
v_{c r}=3.2 \cdot 10^{-2} \cdot \sqrt[3]{K_{s}} \\
v_{c r}=5.0 \cdot 10^{-2} \cdot \sqrt[4]{K_{s}}
\end{gathered}
$$

where:

$V_{\text {out }}$ - water outflow velocity, $\mathrm{m} / \mathrm{d}$

$Q$ - water outflow, $\mathrm{m}^{3} / \mathrm{d}$

$A$ - unit water outflow area, $\mathrm{m}^{2}$

$v_{c r}-$ critical water flow velocity, $\mathrm{m} / \mathrm{s}$

$K_{S}$ - saturated hydraulic conductivity coefficient, $\mathrm{m} / \mathrm{s}$

\section{Results}

The simulation of the leakage from household connection was proceeded in FEFLOW until the moment of full saturation of the soil profile, at the reference point 1. The visualisation of the saturation of the soil profile, in the moment of water outflow, and the graph of saturation changes in reference points are presented in Fig. 4. Laboratory and numerical results of time between the start of the water leakage from a damaged household connection and the occurrence of water outflow on the soil surface are presented in table 2 .

During the numerical simulation, full saturation in reference point 1 was reached at 490-time step of the simulation, which equals $2.072554 \cdot 10^{-5} \mathrm{~d}$, which is
$1.7907 \mathrm{~s}$ after the occurrence of household connection failure (reflection of $17.9 \mathrm{~s}$ in real conditions). The laboratory results in 6 analysed variants were close (variant L3 and L4) as well as far from (L1, L6) the numerical simulation time. However, the mean values of the water time outflow from laboratory investigation are satisfactory close to the reference numerical result (relative error (RE) equals 0.43\%). Reflecting the obtained results into real conditions, it can be expected that the water after a household connection failure will outflow to the soil surface almost immediately - in less than 30 seconds, considering similar soil, pressure and hydraulic conditions. Additionally, the numerical result of water outflow time was compared with the results of field research investigation.

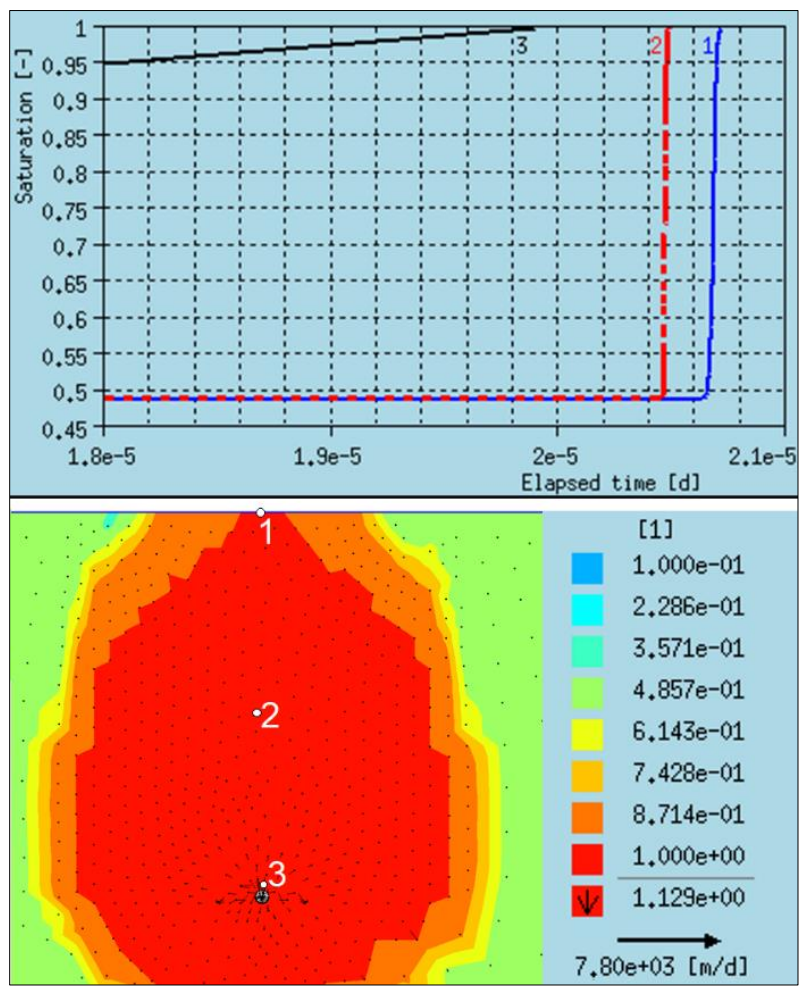

Fig. 4. Saturation of the soil profile in the moment of the water outflow to the soil surface and the graph of saturation changes

\begin{tabular}{|c|c|c|c|c|c|}
\hline simulation & \multicolumn{3}{|c|}{ laboratory } & \multicolumn{2}{|c|}{ field research } \\
\hline $\begin{array}{l}\text { time } \\
\text { (s) }\end{array}$ & \multicolumn{2}{|c|}{$\begin{array}{l}\text { time } \\
\text { (s) }\end{array}$} & $\begin{array}{l}\mathrm{RE} \\
(\%)\end{array}$ & $\begin{array}{c}\text { time } \\
\text { (s) }\end{array}$ & $\begin{array}{l}\mathrm{RE} \\
(\%)\end{array}$ \\
\hline \multirow{7}{*}{1.79} & L1 & 1.35 & 32.6 & \multirow{3}{*}{1.34} & \multirow{3}{*}{33.6} \\
\hline & L2 & 1.57 & 14.1 & & \\
\hline & L3 & 1.72 & 4.1 & & \\
\hline & L4 & 1.95 & 8.2 & \multirow{3}{*}{1.73} & \multirow{3}{*}{3.5} \\
\hline & L5 & 2.08 & 13.9 & & \\
\hline & L6 & 2.12 & 15.5 & & \\
\hline & Mean & 1.8 & 0.43 & 1.53 & 17.0 \\
\hline
\end{tabular}
in reference points $1,2,3$.

Table 2. Laboratory and numerical results of water outflow time from a damaged household connection. 
Field research was conducted for 2 variants of similar hydraulic $\left(\mathrm{H}=40.68\right.$ and $\left.41.50 \mathrm{~m} \mathrm{H}_{2} \mathrm{O}\right)$ and soil in excavation parameters. In both cases, the water outflow occurred in the excavation, so different natural soil parameters were neglected in conditions of this comparison. The obtained results, scaled 1:10, were close $(1.73 \mathrm{~s}, \mathrm{RE}=3.5 \%)$ and less similar $(1.34 \mathrm{~s}, \mathrm{RE}=$ $33.6 \%$ ) to simulated outflow time.

The value of potential lost water as the effect of household connection breakage was calculated using the FEFLOW Fluid Flux Analyzer, which screen capture is presented in Fig. 5. The total outside flux from the household connection pipe equals $71.505 \mathrm{~m}^{3} / \mathrm{d}$ per $\mathrm{m}$ depth. In real conditions, such outflow corresponds with $7.15 \mathrm{~m}^{3}$ of lost water per day, and $50.05 \mathrm{~m}^{3}$ of lost water weekly through household water connection failure.

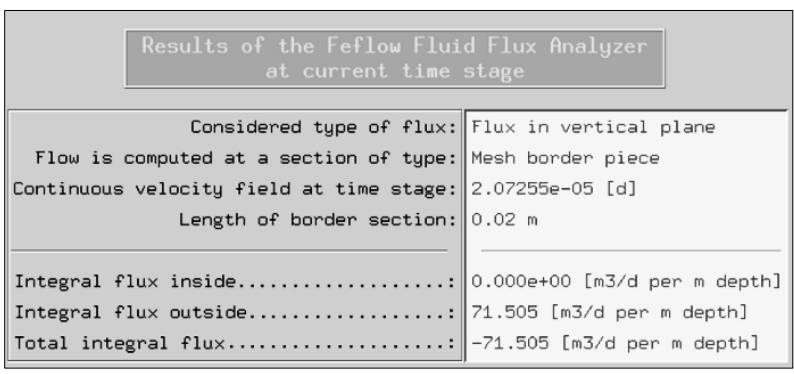

Fig. 5. Screen capture of the FEFLOW Fluid Flux Analyzer.

The possibility of suffosion effect occurrence was defined by comparison of water outflow velocity value with critical water outflow velocity values. The obtained results for real conditions are presented in table 3. On the basis of obtained results, it is possible, that in analysed case the suffosion effect will occur (water outflow velocity is greater than critical values). Additionally, the profile of water velocity outflow from FEFLOW software (reflecting laboratory conditions) is presented in Fig. 6.

Table 3. Water outflow velocity and critical outflow velocities.

\begin{tabular}{|c|c|c|}
\hline water outflow velocity & value $(\mathrm{m} / \mathrm{s})$ & \multirow{2}{*}{ suffosion } \\
\cline { 1 - 2 }$v_{\text {out }}$ & 0.0439 & \\
\hline Sichardt $v_{c r}$ & 0.0012 & + \\
\hline Abramov $v_{c r}$ & 0.0022 & + \\
\hline Schmieder $v_{c r}$ & 0.0068 & + \\
\hline
\end{tabular}

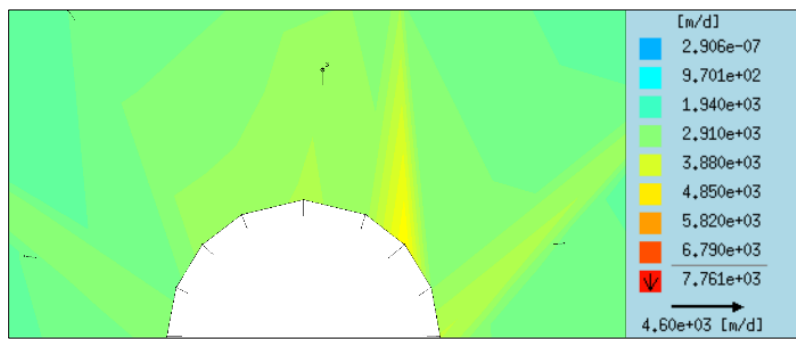

Fig. 6. Profile of water velocity outflow.

\section{Conclusions}

The laboratory, numerical and field results of water outflow time from a damaged household connection were similar to each other, which confirms the correctness of performed investigations. It is very probable, that in corresponding real conditions (DN65, $40 \mathrm{~m} \mathrm{H}_{2} \mathrm{O}$ ), leaking water from household connection will almost immediately outflow to the soil surface and the pipe failure could be quickly located and fixed. However, if the leakage will be of a background character and water will infiltrate the soil, the significant volumes of water will be lost (over $7 \mathrm{~m}^{3}$ per day). Moreover, in the analysed case, the leakage area was the whole circumference of the pipe which not always happens in real conditions. The smaller the leaking area, the longer potential time of water surface outflow is; thus, greater water losses are possible. Additionally, considering similar pipe diameter and hydraulic pressure, it is possible that the suffosion effect will occur around the household connection, causing washing out of solid particles from soil matrix and creating suffosion holes, which can be dangerous for technical infrastructure, health and even humans' lives. Summarising, amount of water lost from a damaged connection can be slight and unnoticed, but the outflow velocity can be large enough to cause a dangerous suffosion effects around the pipe buried in internal unstable soils. In this aspect, the leakages from household connections should not be ignored and removed as soon as possible.

This article was founded by the statutory activity of the Faculty of Environmental Engineering, Lublin University of Technology.

\section{References}

1. J. Rak (ed.), M. Kwietniewski, D. Kowalski, B. Tchórzewska-Cieślak, I. Zimoch, J. Bajer, R. Iwanejko, K. Miszta-Kruk, A. Studziński, K. Boryczko, K. Pietrucha-Urbaniak, I. Piegdoń, Metody oceny niezawodności $i$ bezpieczeństwa dostawy wody do odbiorców (Oficyna wydawnicza Politechniki Rzeszowskiej, Rzeszów, 2013)

2. H. Hotloś, Ilościowa ocena wptywu wybranych czynników na parametry i koszty eksploatacyjne sieci wodociagowych (Wyd. Politechniki Wrocławskiej, Wrocław, 2007)

3. I. Zimoch, Ochr. Sr. 34(4), 57-62 (2012)

4. J. Rak, D. Trojnar, JCEEA t. XXXI, z. 61 (1/14), 245-256 (2014) DOI: 10.7862/rb.2014.17

5. H. Hotloś, Ochr. Sr. 31(2), 41-48 (2009)

6. http://www.igwp.org.pl

7. M. Kutyłowska, Period. Polytech-Civ. 61(3), 548553 (2017) https://doi.org/10.3311/PPci.9997

8. A. Piasecki, J. Jurasz, B. Kaźmierczak, Period. Polytech-Civ. 62(3), 818-824 https://doi.org/10.3311/PPci.11930 
9. M. Kutyłowska, M. Orłowska-Szostak, Water Pract Tech 11(1) 148-156 (2016) DOI: 10.2166/wpt.2016.018

10. M. Iwanek, P. Suchorab, A. Choma, ACEE (11), 133-140 (2018)

11. P. Dohnalik, Z. Jędrzejewski, Efektywna eksploatacja wodociagów: ograniczanie strat wody - to wcale nie trudne... (Wyd. LEMTECH Konsulting, Kraków 2004)

12. S. Speruda, R. Radecki, Ekonomiczny poziom wycieków: modelowanie strat $w$ sieciach wodociagowych (Wyd. Translator s.c. Warszawa 2003)

13. F. Piechurski, Wodociągi-Kanalizacja 3, 40-46, 2015

14. A.L Ragozin, Basic principles of natural hazard risko assessment and management (in: R. Oliviera, L.F. Rpdrigues, A.G. Coehlo, A.P. Cunha (ed.) Proceedings of the $7^{\text {th }}$ International Congress of the International Association of Engineering Geology 3, Lisbon, Portugal, A. A. Balkema, Rotterdam, 12771286, 1994)

15. M. Kwietniewski, J. Rak, Niezawodność infrastruktury wodociagowej $i$ kanalizacyjnej w Polsce (Wyd. PAN, Komitet Inżynierii Lądowej i Wodnej, Instytut Podstawowych Problemów Techniki, Warszawa 2010)

16. A.V. Kadetova, A.A. Rybchenko, Y.B. Trzhcinsky, Bulletin of the Geological Society of Greece 40(3), 1440-1448 (2007)
17. G. Kovács, L. Ujfaludi, HSJ 28(2), 247-260 (1983) https://doi.org/10.1080/02626668309491964

18. V.P. Khomenko, Suffosion hazard: today's and tomorrow's problem for cities (in: M.G. Culshaw, H.J. Reeves, I. Jefferson, T.W. Spink, (ed.) Engineering geology for tomorrow's cities, Geological Society, London, Engineering Geology Special Publication, London 2009)

19. M. Iwanek, P. Suchorab, M. Karpińska-Kiełbasa, Period. Polytech-Civ 61(4), 700-705 (2017) DOI: 10.3311/PPci.9728

20. M.K. Widomski, H. Sobczuk, W. Olszta, Soil Sci. Soc. Am. J. 74, 213-220 (2010) doi:10.2136/ sssaj2009.0003

21. M.K. Widomski, S. Beck Broichsitter, A. Zink, H. Fleife, R. Horn, W. Stępniewski, J.Plant. Nutr. Soil. Sc. 178, 401-412 (2015) https://doi.org/1 0.1002/jpln.201400045

22. I. Krukowski, M. Widomski, M. Iwanek, G. Łagód, Ecol. Chem. Eng. S. 19(3), 311-320 (2012) DOI: 10.2428/ecea.2012.19(03)033

23. P. Suchorab, B. Kowalska, D. Kowalski, Annu. Set. Env. Protection 18(2), 416-427 (2016) http://ros.edu.pl/images/roczniki/2016/No2/31_ROS _N2_V18_R2016.pdf

24. W. Sichardt, Method of stabilization of drilled wells (Julius Spinger, Berlin 1928)

25. C.K. Abramov, Method of calculation and selection of filters for drilled wells (Moscow 1952)

26. A. Schmieder, On the critical velocity in the vicinity of wells (Hidrológiai Közlemények 10, 1966). 